\title{
The Role of XBP-1 in Tumorigenicity
}

\author{
Ayesha N. Shajahan ${ }^{1}$, Rebecca B. Riggins ${ }^{1}$, and Robert Clarke ${ }^{1,2}$ \\ ${ }^{1}$ Department of Oncology, Lombardi Comprehensive Cancer Center, Georgetown University, \\ College of Medicine, 3970 Reservoir Road, N.W., NRB W405, Washington D.C., 20057
}

\begin{abstract}
Rapid growth of a tumor can overwhelm the vasculature that supplies it with nutrients and oxygen. Inside such tumors, cells undergo endoplasmic reticulum (EnR) stress but can survive such adverse microenvironments by an adaptive mechanism called the unfolded protein response (UPR). X-box binding protein-1 (XBP-1) is a critical transcriptional activator of the UPR and is responsible for regulating the function of genes in cell survival. An unconventional splicing of the XBP-1(U) mRNA results in two proteins: XBP-1(S) that is often increased in a variety of human cancers, and any translated proteins from the unspliced XBP-1(U) mRNA that acts as a dominant negative of endogenous XBP-1(S) action. In cancer cells, over-expression of XBP-1 can confer drug resistance by preventing drug-induced cell cycle arrest and mitochondrial permeability and apoptosis while down-regulation of XBP-1 increases the sensitivity to killing by hypoxia. XBP-1 is also implicated in cellular de-differentiation, oncovirus infection and the epithelial-tomesenchymal transition (EMT). Given that XBP-1 mediates a wide range of responses in tumorigenesis, it is logical to focus on XBP-1 as an anti-cancer therapeutic target. Furthermore, combining inhibitors of XBP-1 with other anti-UPR drugs may enhance the activity of some antineoplastic therapies.
\end{abstract}

\section{Introduction}

In poorly vascularized solid tumors, cancer cells face hypoxia and glucose deprivation that disrupt protein folding in their endoplasmic reticulum (EnR) (1). Abnormal accumulation of proteins in the EnR activates an adaptive mechanism called the unfolded protein response (UPR). Initially a compensatory mechanism allowing cells to recover normal EnR function, prolonged UPR may induce cell death; this is often dependent upon which arm of the UPR signaling pathway predominates. The UPR can also activate autophagy (2) but whether this is a pro-survival or pro-death autophagy is unknown, since UPR activation leads to prodeath and pro-survival outcomes (3). Prolonged cell survival in nutrient-limiting conditions or following anti-cancer drug treatment is attained by coordinating the transcription of a complex array of genes in the UPR (4). X-box binding protein-1 (XBP-1), which undergoes unconventional splicing in the cytosol, is an obligate component in two arms of the UPR signaling pathway $(5,6)$. Therefore, compounds that target XBP-1 may have therapeutic activity for the treatment of some cancers.

\section{XBP-1 in UPR}

Transmembrane EnR proteins ATF6, IRE1a (or IRE1 $\beta$ ), and PERK initiate UPR through different signaling pathways that include transcription factors, and that lead in turn to the coordinated expression of multiple UPR target genes $(7,8)$ (Figure 1). Activated ATF6 increases the mRNA level of XBP-1, while IRE1a mediates the unconventional splicing of

\footnotetext{
${ }^{2}$ Address for correspondence: Robert Clarke, Ph.D., D.Sc., Telephone: (202) 687- 7237, Facsimile: (202) 687-7505, clarker@georgetown.edu.
} 
the XBP-1(U) mRNA, the unspliced form, to produce XBP-1(S), the spliced form that is a potent UPR transcriptional activator $(6,9,10)$. XBP-1 belongs to the basic region/leucine zipper (bZIP) family $(11,12)$. XBP-1(S) has a molecular weight of $\sim 54 \mathrm{kDa}$; splicing removes a $26 \mathrm{bp}$ intron and creates a translational frame-shift. XBP-1(U) has a molecular weight of $\sim 33 \mathrm{kDa}$ and acts as a dominant negative $(13,14)$. While both XBP-1 isoforms contains DNA-binding domains, XBP-1(S) contains an activation domain and XBP-1(U) contains a degradation domain (Figure 2). The basic region of the DNA-binding domain functions as a nuclear localization signal (NLS) but only XBP-1(U) contains a nuclear exclusion domain (NES) that enable the protein to shuttle in and out of the nucleus (15). Regulation of transcription by XBP-1(S) is a consequence of its homodimers activating specific cAMP response elements (CREs) with a conserved ACGT core sequence GATGACGTG(T/G) NNN(A/T)T - sometimes called the UPR element $(3,16)$ or the endoplasmic reticulum stress response element I (ERSE-I) (17). XBP-1(U) acts as a dominant-negative inhibitor of the active XBP-1(S) species and can prevent an effective UPR (18).

XBP-1 can induce ER-targeted proteins including glucose-regulated protein 78 (GRP78; $\mathrm{BiP})$, which help resolve EnR stress and foster cell survival (19). Once UPR is initiated, accumulated unfolded protein is either correctly refolded, or degraded through the EnRassociated protein degradation (ERAD) system. However, if the unfolded protein level exceeds a threshold, the affected cells are committed to cell death, which is mediated by ATF4 and ATF6, as well as activation of the JNK/AP-1/Gadd153 or CHOP-signaling pathway (20). While CHOP negatively regulates anti-apoptotic molecules such as BCL-2 (21), the pro-survival NFkappaB can inhibit CHOP activation in breast cancer cells undergoing ER stress (22). Thus, the balance of GRP78 and CHOP expression regulates the UPR-mediated cell survival or cell death. Reduced susceptibility to cell death upon activation of the UPR may contribute to tumor progression (20).

\section{XBP-1 in Cell Survival}

Apoptosis-Apoptosis is defined by morphological criteria related to organized chromatin condensation and fragmentation of the cell nucleus, accompanied by cleavage of DNA, formation of apoptotic bodies, cell shrinkage, and ruffling of the cell membrane $(23,24)$. Apoptosis is a form of programmed cell death, and primarily, two major pathways are involved: intrinsic and extrinsic pathways. The intrinsic (mitochondrial) pathway is regulated by the proapoptotic and antiapoptotic BCL2 family members; this pathway involves changes in mitochondrial membrane permeability (MMP), release of cytochrome $c$, exposure of phosphatidylserine, and the eventual loss of plasma membrane integrity (25). The extrinsic (cell surface receptor) pathway is dependent upon extracellular signals including tissue necrosis factor-a (TNFa), Fas ligand, and TNF-related ligand TRAIL (24, 26). Both of these pathways can activate caspases that cleave DNA and catabolize the cytoskeleton, resulting in cell death.

Considering the association between UPR and tumor development, pharmacological inducers of ER stress that selectively promote apoptosis while disrupting the pro-survival UPR molecules could be promising anticancer therapeutic agents. The anticancer drug resveratrol, a naturally occurring polyphenolic compound highly enriched in grapes and red wine, has been reported to induce apoptosis in response to EnR stress followed by XBP-1 splicing (27). Bortezomib, a 26S proteasome inhibitor, was shown to induce apoptosis in multiple myeloma cells by inducing UPR and preventing pro-survival UPR components such as BiP and XBP-1 (28). 
Autophagy - In the process of autophagy, cytoplasmic contents are degraded by double/ multi-membrane vacuoles or autophagosomes, normally resulting in the removal of defective or damaged organelles, e.g., mitochondria. Autophagy can be classified into three forms: microautophagy, chaperone- mediated autophagy, and macroautophagy (29). Autophagy can be either pro-death and act as an alternative cell death pathway to apoptosis, or pro-survival when extracellular nutrients or growth factors are limited (30). Pro-survival outcomes likely reflect an adequate adjustment to stress, with energy/nutrients recovered from the organelles "digested" in the autophagosomes. Pro-death outcomes may arise when the self-digestion of autophagy leads to such a loss of organelles that the cell can no longer survive. In cancer cells, autophagy induction can accelerate cell death $(31,32)$ or promote cell survival (33-35), independently or in response to treatment with cytotoxic agents.

Morphologically, autophagy can be identified by the formation of double-membrane structures called autophagosomes, absence of marginated nuclear chromatin, and/or the presence of cytoplasmic vacuoles using monodansylcadaverine $(36,37)$. At the molecular level, autophagy can also be classified by assessing the cleavage of LC3, accumulation of GFP-LC3-labeled autophagosomes $(38,39)$, and degradation of p62/SQSTM1 by autophagosomes $(38,40)$. UPR (initiated by XBP-1 splicing by IRE1 $a$ ) activation can induce autophagy through JNK activation and eIF2a phosphorylation (2). Other key regulators of autophagy are now known to include BCL2 family members (41-43) and their interacting proteins such as Beclin-1/ATG6 (BECN1) (44). BCL2 antiapoptotic proteins, which are regulated by XBP-1(S) (45) can block autophagy by inhibiting BECN1 (46). Mono-allelic loss of the BECN1 locus occurs in $>40 \%$ of breast cancers (47) (and in MCF-7 cells), and thus, modulating the XBP-1/BCL2 pathway may be an effective mechanism for regulating autophagic cell death. The early events in autophagy may be reversible, while the later events may (or appear to) share mechanisms with other cell death pathways. A switch from autophagy to apoptosis occurs, for example, following upregulation of BID (42).

\section{XBP-1 and Cancer Progression}

XBP-1 is ubiquitously expressed in adult tissue. In breast tumors, higher XBP-1 mRNA is expressed in estrogen receptor a (ERa)-positive breast tumors than in ERa-negative breast tumors (48-52) and SAGE (serial analysis of gene expression) showed XBP-1 to be highly expressed in cancerous mammary epithelial cells (53). Investigation of the transcriptomes of antiestrogen-responsive (MCF7/LCC1) and -resistant variants(MCF7/LCC9) of the MCF-7 human breast cancer cell line revealed upregulation of the XBP-1 gene in MCF7/LCC9 cells compared with MCF7/LCC1 cells (54). While these studies may not differentiate between $\mathrm{XBP}-1(\mathrm{U})$ and XBP-1(S) or the sum of these signals, XBP-1 isoforms have been recently shown to be differentially associated with outcome of endocrine therapy for breast cancer patients. Higher levels of dominant-negative XBP-1(U) favor apoptosis of tumor cells and higher levels of XBP-1(S) increase tumor cell survival (55). We have shown that overexpression of XBP-1 (S) in ERa-positive breast cancer cells leads to estrogenindependent growth and reduced sensitivity to growth inhibition induced by the antiestrogens (45). Table 1 shows genes that are known to be regulated by XBP-1 in breast cancer cells. Immunohistochemical staining showed increased XBP-1 protein in the cytoplasm of cancer cells but almost none in non-cancerous breast tissue (56). Thus, XBP-1 may promote human breast carcinogenesis through impairment of cell differentiation regulation (57).

XBP-1(S) and XBP-1(U) interact with the DNA-binding domain of ERa and the ERainteracting regions on XBP-1(S) and XBP-1(U) have been mapped to two regions: the Nterminal basic region leucine zipper domain (bZIP) and the C-terminal activation domain. Moreover, $\mathrm{XBP}-1(\mathrm{~S})$ as well as XBP-1(U) increase ERa-dependent transcriptional activity 
in a ligand-independent manner (16) by regulation of large-scale chromatin unfolding (58) while deletion of the N-terminal portion of XBP-1(S) and XBP-1(U) fully abolishes their ability to regulate $\mathrm{ERa}$ transcriptional activity.

Hypoxia-Within solid tumors, hypoxia is a physiologically important cause of ER stress. Hypoxia is associated with decreased local control, increased distant metastases, and decreased overall survival in a variety of human tumors (59). Down-regulation of XBP-1 increases the sensitivity of transformed human cells to killing by hypoxia and severely impedes tumor growth without affecting angiogenesis (60). Thus, targeting XBP-1 can be used as a therapeutic strategy to eliminate hypoxic cells and inhibit tumor growth

Drug Resistance-In breast cancer, over-expression of XBP-1(S) in ER-positive breast cancer cells prevents antiestrogen-induced cell cycle arrest and cell death through the mitochondrial apoptotic pathway. XBP-1(S) also confers estrogen-independence and antiestrogen cross-resistance (45). XBP-1 is rapidly induced in response to E2-stimulation $(61,62)$ and XBP-1(S) can bind to and activate ERa in a ligand-independent manner (16). These activities of XBP-1 are closely related to the complex biological consequences of initiating, or failing to initiate, an appropriate UPR.

Cell Differentiation-EnR stress can cause de-differentiation of both primary and immortalized cells and this event may be instrumental in the survival and recovery function of the UPR $(63,64)$. Cells adapt to stress by down-regulating genes, which are involved in differentiation, at the levels of their transcription or translation, $(65,66)$. EnR stress may induce de-differentiation in those cells whose phenotype is associated with the synthesis of numerous proteins in the EnR. In thyroid cells, EnR induced de-differentiation is also associated with an epithelial-to-mesenchymal transition (EMT)-like phenotype (64), a hallmark for cancer progression. XBP-1 is know to be essential for the development of highly secretory exocrine cells and is believed to be involved in UPR-dependent EnR expansion (67). Although the function of XBP-1 in membrane biogenesis in cancer cells is unknown, it is possible that XBP-1's ability to affect phospholipid biosynthesis may be part of an adaptive response in cancer cells that enable them to survive EnR stress.

Viral infection-Several viruses are known to initiate UPR in host cells following infection (68-71). Among them are oncoviruses such as the human T-lymphotropic virus type 1 (HTLV-1) that is a causative agent of adult T-cell leukemia/lymphoma (69) and the Epstein-Barr virus (EBV) that is associated with Burkitt's lymphoma, breast and gastric cancer $(68,72)$. XBP-1(S) can activate the transcription of HTLV-1 (69) and induce the switch from latent to lytic EBV infection (72) and thus, the coordination between viral activation and cell differentiation enables oncovirus-mediated carcinogenesis.

\section{Conclusions}

Under normal conditions, the EnR provides a unique location that assists in proper protein folding and assures that only correctly folded proteins advance in the secretory pathway. However, when a cell is deprived of nutrients or oxygen, such as the microenvironments deep inside a tumor, accumulation of proteins can occur in the EnR that can trigger UPR (73). Although the UPR is a well-conserved adaptive mechanism that ensures proper protein folding or apoptosis, this process can also promote cell survival. UPR activation of ERAD may support the "reusing" of materials recovered from the degradation of misfolded proteins, which could also allow cells to survive when extracellular nutrient sources are limited. XBP-1 is a key gene that is induced by the UPR. XBP-1(S) can activate a variety of genes involved in protein maturation, degradation or EnR expansion that enables the cells to 
efficiently produce and secrete proteins. XBP-1 has also been linked to tumor cell responses to hypoxia, drug therapy, cellular differentiation and oncovirus infections. Thus, pharmacological inhibitors of the XBP-1-mediated UPR pathway could be important anticancer therapeutic tools.

\section{Acknowledgments}

This work was supported in part by a Department of Defense awardW81XWH-08-1-0319 (RC) from the United States Army Medical Research and Materiel Command, and a Susan G. Komen for the Cure Fellowship award PDF0600477 (ANS).

\section{References}

1. Brown JM, Giaccia AJ. The unique physiology of solid tumors: opportunities (and problems) for cancer therapy. Cancer Res. 1998; 58:1408-1416. [PubMed: 9537241]

2. Ogata M, Hino S, Saito A, et al. Autophagy is activated for cell survival after endoplasmic reticulum stress. Mol Cell Biol. 2006; 26:9220-9231. [PubMed: 17030611]

3. Feldman DE, Chauhan V, Koong AC. The unfolded protein response: a novel component of the hypoxic stress response in tumors. Mol Cancer Res. 2005; 3:597-605. [PubMed: 16317085]

4. Kaufman RJ, Scheuner D, Schroder M, Shen X, Lee K, Liu CY, Arnold SM. The unfolded protein response in nutrient sensing and differentiation. Nat Rev Mol Cell Biol. 2002; 3:411-421. [PubMed: 12042763]

5. DuRose JB, Tam AB, Niwa M. Intrinsic capacities of molecular sensors of the unfolded protein response to sense alternate forms of endoplasmic reticulum stress. Mol Biol Cell. 2006; 17:30953107. [PubMed: 16672378]

6. Yoshida H, Matsui T, Yamamoto A, Okada T, Mori K. XBP1 mRNA is induced by ATF6 and spliced by IRE1 in response to ER stress to produce a highly active transcription factor. Cell. 2001; 107:881-891. [PubMed: 11779464]

7. Harding HP, Calfon M, Urano F, Novoa I, Ron D. Transcriptional and translational control in the Mammalian unfolded protein response. Annu Rev Cell Dev Biol. 2002; 18:575-599. [PubMed: 12142265]

8. Ma Y, Hendershot LM. The unfolding tale of the unfolded protein response. Cell. 2001; 107:827830. [PubMed: 11779459]

9. Calfon M, Zeng H, Urano F, et al. IRE1 couples endoplasmic reticulum load to secretory capacity by processing the XBP-1 mRNA. Nature. 2002; 415:92-96. [PubMed: 11780124]

10. Lee K, Tirasophon W, Shen X, et al. IRE1-mediated unconventional mRNA splicing and S2Pmediated ATF6 cleavage merge to regulate XBP1 in signaling the unfolded protein response. Genes Dev. 2002; 16:452-466. [PubMed: 11850408]

11. Clauss IM, Gravallese EM, Darling JM, Shapiro F, Glimcher MJ, Glimcher LH. In situ hybridization studies suggest a role for the basic region-leucine zipper protein hXBP-1 in exocrine gland and skeletal development during mouse embryogenesis. Dev Dyn. 1993; 197:146-156. [PubMed: 7693055]

12. Liou HC, Boothby MR, Finn PW, Davidon R, Nabavi N, Zeleznik-Le NJ, Ting JP, Glimcher LH. A new member of the leucine zipper class of proteins that binds to the HLA DR alpha promoter. Science. 1990; 247:1581-1584. [PubMed: 2321018]

13. Lee AH, Iwakoshi NN, Glimcher LH. XBP-1 regulates a subset of endoplasmic reticulum resident chaperone genes in the unfolded protein response. Mol Cell Biol. 2003; 23:7448-7459. [PubMed: 14559994]

14. Sriburi R, Jackowski S, Mori K, Brewer JW. XBP1: a link between the unfolded protein response, lipid biosynthesis, and biogenesis of the endoplasmic reticulum. J Cell Biol. 2004; 167:35-41. [PubMed: 15466483]

15. Yoshida H. Unconventional splicing of XBP-1 mRNA in the unfolded protein response. Antioxid Redox Signal. 2007; 9:2323-2333. [PubMed: 17979529] 
16. Ding L, Yan J, Zhu J, Zhong H, Lu Q, Wang Z, Huang C, Ye Q. Ligand-independent activation of estrogen receptor alpha by XBP-1. Nucleic Acids Res. 2003; 31:5266-5274. [PubMed: 12954762]

17. Lacroix M, Leclercq G. About GATA3, HNF3A, and XBP1, three genes co-expressed with the oestrogen receptor-alpha gene (ESR1) in breast cancer. Mol Cell Endocrinol. 2004; 219:1-7. [PubMed: 15149721]

18. Lee AH, Iwakoshi NN, Anderson KC, Glimcher LH. Proteasome inhibitors disrupt the unfolded protein response in myeloma cells. Proc Natl Acad Sci U S A. 2003; 100:9946-9951. [PubMed: 12902539]

19. Shuda M, Kondoh N, Imazeki N, et al. Activation of the ATF6, XBP1 and grp78 genes in human hepatocellular carcinoma: a possible involvement of the ER stress pathway in hepatocarcinogenesis. J Hepatol. 2003; 38:605-614. [PubMed: 12713871]

20. Kim R, Emi M, Tanabe K, Murakami S. Role of the unfolded protein response in cell death. Apoptosis. 2006; 11:5-13. [PubMed: 16374548]

21. McCullough KD, Martindale JL, Klotz LO, Aw TY, Holbrook NJ. Gadd153 sensitizes cells to endoplasmic reticulum stress by down-regulating $\mathrm{Bcl} 2$ and perturbing the cellular redox state. Mol Cell Biol. 2001; 21:1249-1259. [PubMed: 11158311]

22. Nozaki S, Sledge GW Jr, Nakshatri H. Repression of GADD153/CHOP by NF-kappaB: a possible cellular defense against endoplasmic reticulum stress-induced cell death. Oncogene. 2001; 20:2178-2185. [PubMed: 11360202]

23. Riggins, RB.; Bouton, AH.; Liu, MC.; Clarke, R. Antiestrogens, aromatase inhibitors, and apoptosis in breast cancer. In: Litwack, G., editor. Vitamins and Hormones. Vol. 71. Elsevier Academic Press; London: 2005. p. 201-237.

24. Zhivotovsky B, Kroemer G. Apoptosis and genomic instability. Nat Rev Mol Cell Biol. 2004; 5:752-762. [PubMed: 15340382]

25. Goldstein JC, Waterhouse NJ, Juin P, Evan GI, Green DR. The coordinate release of cytochrome c during apoptosis is rapid, complete and kinetically invariant. Nat Cell Biol. 2000; 2:156-162. [PubMed: 10707086]

26. Brown JM, Attardi LD. The role of apoptosis in cancer development and treatment response. Nat Rev Cancer. 2005; 5:231-237. [PubMed: 15738985]

27. Park JW, Woo KJ, Lee JT, Lim JH, Lee TJ, Kim SH, Choi YH, Kwon TK. Resveratrol induces pro-apoptotic endoplasmic reticulum stress in human colon cancer cells. Oncol Rep. 2007; 18:1269-1273. [PubMed: 17914584]

28. Gu H, Chen X, Gao G, Dong H. Caspase-2 functions upstream of mitochondria in endoplasmic reticulum stress-induced apoptosis by bortezomib in human myeloma cells. Mol Cancer Ther. 2008; 7:2298-2307. [PubMed: 18723477]

29. Klionsky DJ, Emr SD. Autophagy as a regulated pathway of cellular degradation. Science. 2000; 290:1717-1721. [PubMed: 11099404]

30. Jin S. Autophagy, mitochondrial quality control, and oncogenesis. Autophagy. 2006; 2:80-84. [PubMed: 16874075]

31. Park MA, Yacoub A, Sarkar D, et al. PERK-dependent regulation of MDA-7/IL-24-induced autophagy in primary human glioma cells. Autophagy. 2008; 4:513-515. [PubMed: 18299661]

32. Yan CH, Yang YP, Qin ZH, Gu ZL, Reid P, Liang ZQ. Autophagy is involved in cytotoxic effects of crotoxin in human breast cancer cell line MCF-7 cells. Acta Pharmacol Sin. 2007; 28:540-548. [PubMed: 17376294]

33. Apel A, Herr I, Schwarz H, Rodemann HP, Mayer A. Blocked autophagy sensitizes resistant carcinoma cells to radiation therapy. Cancer Res. 2008; 68:1485-1494. [PubMed: 18316613]

34. Boya P, Gonzalez-Polo RA, Casares N, et al. Inhibition of macroautophagy triggers apoptosis. Mol Cell Biol. 2005; 25:1025-1040. [PubMed: 15657430]

35. Li M, Jiang X, Liu D, Na Y, Gao GF, Xi Z. Autophagy protects LNCaP cells under androgen deprivation conditions. Autophagy. 2008; 4:54-60. [PubMed: 17993778]

36. Broker LE, Kruyt FA, Giaccone G. Cell death independent of caspases: a review. Clin Cancer Res. 2005; 11:3155-3162. [PubMed: 15867207]

37. Edinger AL, Thompson CB. Death by design: apoptosis, necrosis and autophagy. Curr Opin Cell Biol. 2004; 16:663-669. [PubMed: 15530778] 
38. Klionsky DJ, Abeliovich H, Agostinis P, et al. Guidelines for the use and interpretation of assays for monitoring autophagy in higher eukaryotes. Autophagy. 2008; 4:151-175. [PubMed: 18188003]

39. Mizushima N, Yoshimori T. How to interpret LC3 immunoblotting. Autophagy. 2007; 3:542-545. [PubMed: 17611390]

40. Pankiv S, Clausen TH, Lamark T, Brech A, Bruun JA, Outzen H, Overvatn A, Bjorkoy G, Johansen T. p62/SQSTM1 binds directly to Atg8/LC3 to facilitate degradation of ubiquitinated protein aggregates by autophagy. J Biol Chem. 2007; 282:24131-24145. [PubMed: 17580304]

41. Akar U, Chaves-Reyez A, Barria M, et al. Silencing of Bcl-2 expression by small interfering RNA induces autophagic cell death in MCF-7 breast cancer cells. Autophagy. 2008; 4:669-679. [PubMed: 18424910]

42. Lamparska-Przybysz M, Gajkowska B, Motyl T. BID-deficient breast cancer MCF-7 cells as a model for the study of autophagy in cancer therapy. Autophagy. 2006; 2:47-48. [PubMed: 16874058]

43. Shimizu S, Kanaseki T, Mizushima N, Mizuta T, rakawa-Kobayashi S, Thompson CB, Tsujimoto Y. Role of Bcl-2 family proteins in a non-apoptotic programmed cell death dependent on autophagy genes. Nat Cell Biol. 2004; 6:1221-1228. [PubMed: 15558033]

44. Furuya N, Yu J, Byfield M, Pattingre S, Levine B. The evolutionarily conserved domain of Beclin 1 is required for Vps34 binding, autophagy and tumor suppressor function. Autophagy. 2005; 1:46-52. [PubMed: 16874027]

45. Gomez BP, Riggins RB, Shajahan AN, et al. Human X-box binding protein-1 confers both estrogen independence and antiestrogen resistance in breast cancer cell lines. FASEB J. 2007; 21:4013-4027. [PubMed: 17660348]

46. Pattingre S, Tassa A, Qu X, Garuti R, Liang XH, Mizushima N, Packer M, Schneider MD, Levine B. Bcl-2 antiapoptotic proteins inhibit Beclin 1-dependent autophagy. Cell. 2005; 122:927-939. [PubMed: 16179260]

47. Liang XH, Jackson S, Seaman M, Brown K, Kempkes B, Hibshoosh H, Levine B. Induction of autophagy and inhibition of tumorigenesis by beclin 1. Nature. 1999; 402:672-676. [PubMed: 10604474]

48. Bertucci F, Houlgatte R, Benziane A, et al. Gene expression profiling of primary breast carcinomas using arrays of candidate genes. Hum Mol Genet. 2000; 9:2981-2991. [PubMed: 11115842]

49. Iwao K, Matoba R, Ueno N, Ando A, Miyoshi Y, Matsubara K, Noguchi S, Kato K. Molecular classification of primary breast tumors possessing distinct prognostic properties. Hum Mol Genet. 2002; 11:199-206. [PubMed: 11809729]

50. Perou CM, Sorlie T, Eisen MB, et al. Molecular portraits of human breast tumours. Nature. 2000; 406:747-752. [PubMed: 10963602]

51. van' V, Dai H, van d V, et al. Gene expression profiling predicts clinical outcome of breast cancer. Nature. 2002; 415:530-536. [PubMed: 11823860]

52. West M, Blanchette C, Dressman H, et al. Predicting the clinical status of human breast cancer by using gene expression profiles. Proc Natl Acad Sci U S A. 2001; 98:11462-11467. [PubMed: 11562467]

53. Porter DA, Krop IE, Nasser S, Sgroi D, Kaelin CM, Marks JR, Riggins G, Polyak K. A SAGE (serial analysis of gene expression) view of breast tumor progression. Cancer Res. 2001; 61:56975702. [PubMed: 11479200]

54. Gu Z, Lee RY, Skaar TC, et al. Association of interferon regulatory factor-1, nucleophosmin, nuclear factor-kappaB, and cyclic AMP response element binding with acquired resistance to Faslodex (ICI 182,780). Cancer Res. 2002; 62:3428-3437. [PubMed: 12067985]

55. Davies MP, Barraclough DL, Stewart C, Joyce KA, Eccles RM, Barraclough R, Rudland PS, Sibson DR. Expression and splicing of the unfolded protein response gene XBP-1 are significantly associated with clinical outcome of endocrine-treated breast cancer. Int J Cancer. 2008; 123:8588. [PubMed: 18386815]

56. Zhu Y, Singh B, Hewitt S, Liu A, Gomez B, Wang A, Clarke R. Expression patterns among interferon regulatory factor-1, human X-box binding protein-1, nuclear factor kappa B, 
nucleophosmin, estrogen receptor-alpha and progesterone receptor proteins in breast cancer tissue microarrays. Int J Oncol. 2006; 28:67-76. [PubMed: 16327981]

57. Fujimoto T, Onda M, Nagai H, Nagahata T, Ogawa K, Emi M. Upregulation and overexpression of human X-box binding protein 1 (hXBP-1) gene in primary breast cancers. Breast Cancer. 2003; 10:301-306. [PubMed: 14634507]

58. Fang Y, Yan J, Ding L, et al. XBP-1 increases ERalpha transcriptional activity through regulation of large-scale chromatin unfolding. Biochem Biophys Res Commun. 2004; 323:269-274. [PubMed: 15351732]

59. Vaupel P, Kelleher DK, Hockel M. Oxygen status of malignant tumors: pathogenesis of hypoxia and significance for tumor therapy. Semin Oncol. 2001; 28:29-35. [PubMed: 11395850]

60. Romero-Ramirez L, Cao H, Nelson D, et al. XBP1 is essential for survival under hypoxic conditions and is required for tumor growth. Cancer Res. 2004; 64:5943-5947. [PubMed: 15342372]

61. Tozlu S, Girault I, Vacher S, Vendrell J, Andrieu C, Spyratos F, Cohen P, Lidereau R, Bieche I. Identification of novel genes that co-cluster with estrogen receptor alpha in breast tumor biopsy specimens, using a large-scale real-time reverse transcription-PCR approach. Endocr Relat Cancer. 2006; 13:1109-1120. [PubMed: 17158757]

62. Wang DY, Fulthorpe R, Liss SN, Edwards EA. Identification of estrogen-responsive genes by complementary deoxyribonucleic acid microarray and characterization of a novel early estrogeninduced gene: EEIG1. Mol Endocrinol. 2004; 18:402-411. [PubMed: 14605097]

63. Yang L, Carlson SG, McBurney D, Horton WE Jr. Multiple signals induce endoplasmic reticulum stress in both primary and immortalized chondrocytes resulting in loss of differentiation, impaired cell growth, and apoptosis. J Biol Chem. 2005; 280:31156-31165. [PubMed: 16000304]

64. Ulianich L, Garbi C, Treglia AS, Punzi D, Miele C, Raciti GA, Beguinot F, Consiglio E, Di JB. ER stress is associated with dedifferentiation and an epithelial-to-mesenchymal transition-like phenotype in PC Cl3 thyroid cells. J Cell Sci. 2008; 121:477-486. [PubMed: 18211961]

65. Pirot P, Naamane N, Libert F, Magnusson NE, Orntoft TF, Cardozo AK, Eizirik DL. Global profiling of genes modified by endoplasmic reticulum stress in pancreatic beta cells reveals the early degradation of insulin mRNAs. Diabetologia. 2007; 50:1006-1014. [PubMed: 17333111]

66. Tsang KY, Chan D, Cheslett D, et al. Surviving endoplasmic reticulum stress is coupled to altered chondrocyte differentiation and function. PLoS Biol. 2007; 5:e44. [PubMed: 17298185]

67. Lee AH, Chu GC, Iwakoshi NN, Glimcher LH. XBP-1 is required for biogenesis of cellular secretory machinery of exocrine glands. EMBO J. 2005; 24:4368-4380. [PubMed: 16362047]

68. Sun CC, Thorley-Lawson DA. Plasma cell-specific transcription factor XBP-1s binds to and transactivates the Epstein-Barr virus BZLF1 promoter. J Virol. 2007; 81:13566-13577. [PubMed: 17898050]

69. Ku SC, Lee J, Lau J, Gurumurthy M, Ng R, Lwa SH, Lee J, Klase Z, Kashanchi F, Chao SH. XBP-1, a novel human T-lymphotropic virus type 1 (HTLV-1) tax binding protein, activates HTLV-1 basal and tax-activated transcription. J Virol. 2008; 82:4343-4353. [PubMed: 18287238]

70. Umareddy I, Pluquet O, Wang QY, Vasudevan SG, Chevet E, Gu F. Dengue virus serotype infection specifies the activation of the unfolded protein response. J Virol. 2007; 4:91.

71. Tirosh B, Iwakoshi NN, Lilley BN, Lee AH, Glimcher LH, Ploegh HL. Human cytomegalovirus protein US11 provokes an unfolded protein response that may facilitate the degradation of class I major histocompatibility complex products. J Virol. 2005; 79:2768-2779. [PubMed: 15708995]

72. Bhende PM, Dickerson SJ, Sun X, Feng WH, Kenney SC. X-box-binding protein 1 activates lytic Epstein-Barr virus gene expression in combination with protein kinase D. J Virol. 2007; 81:73637370. [PubMed: 17494074]

73. Koong AC, Chauhan V, Romero-Ramirez L. Targeting XBP-1 as a novel anti-cancer strategy. Cancer Biol Ther. 2006; 5:756-759. [PubMed: 16861911] 


\section{Endoplasmic Reticulum Cytoplasm}

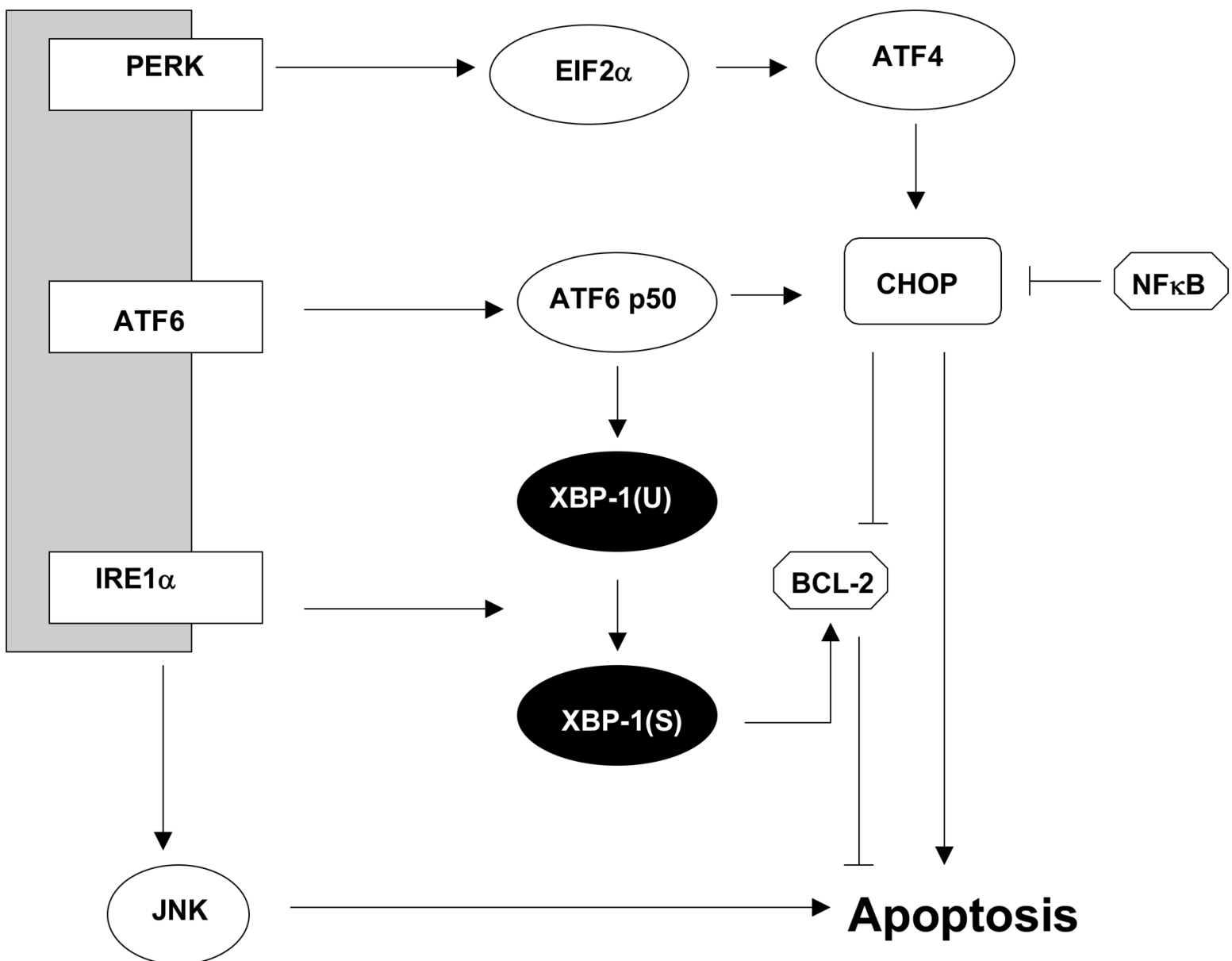

Figure 1.

Schematic diagram of XBP-1 in the UPR Signaling Pathway. XBP-1 is located at a critical junction in this pathway that controls pro-death and pro-survival signals. 


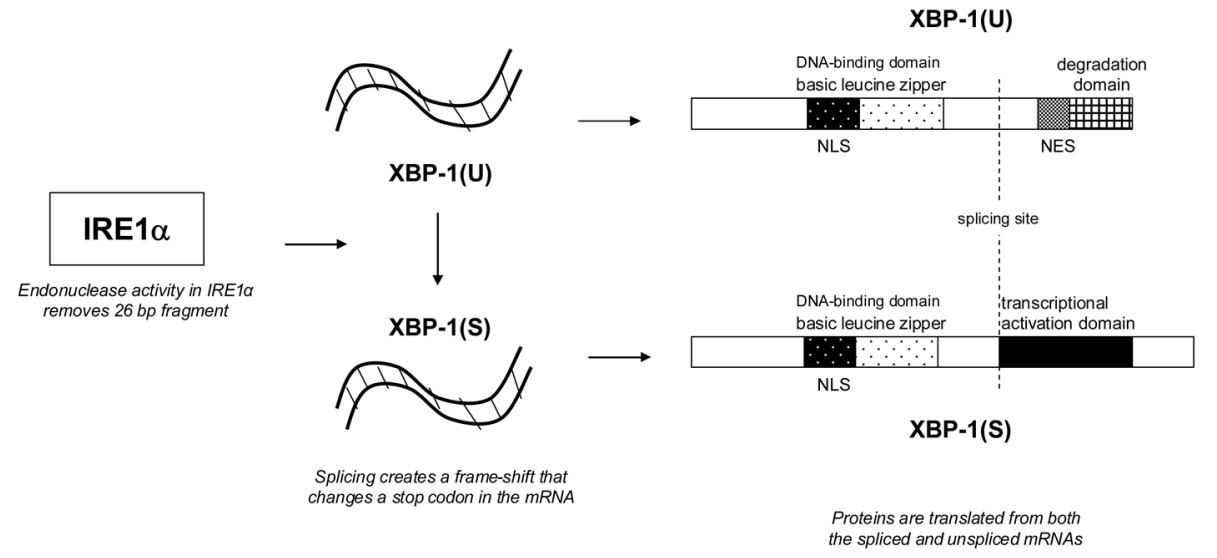

Figure 2.

Unconventional splicing of XBP-1. This splicing is considered unconventional because it occurs in the cytoplasm. Endonuclease activity in IRE1a removes a 26 bp fragment from a conserved stem-loop region of XBP-1 RNA, resulting in two spliced variants. The sizes of the resulting proteins, XBP-1(U) and XBP-1(S), are $\sim 33 \mathrm{kDa}$ and $\sim 54 \mathrm{kDa}$, respectively. The DNA-binding domain and nuclear localization signal (NLS) are present on both isoforms. The nuclear exclusion signal (NES) domain and the degradation domain are unique to $\mathrm{XBP}-1(\mathrm{U})$ while the transcriptional activation domain is unique to $\mathrm{XBP}-1(\mathrm{~S})$. 
Table 1

Genes Regulated by XBP1 in breast cancer cells. (Modified from Ref. 44 with permission)

\begin{tabular}{llccc}
\hline Symbol & Gene Name & Change & p-value & \# CREs \\
\hline APBB2 & amyloid beta (A4) precursor protein-binding & -1.3 & 0.001 & 1 \\
BCL2 & B-cell CLL/lymphoma 2 & 3.1 & 0.029 & 3 \\
CRK & v-crk sarcoma virus CT10 oncogene homolog & -2.0 & 0.003 & 2 \\
ESR1 & estrogen receptor alpha (ERa) & 2.8 & 0.040 & $0 *$ \\
IL24 & interleukin 24 & -9.7 & $<0.001$ & 1 \\
MYC & v-mycmyelocytomatosis viral oncogene homolog & 1.6 & 0.04 & 1 \\
PHLDA2 & pleckstrin homology-like domain, family A, member 2 & -3.3 & 0.004 & 2 \\
S100A6 & S100 calcium binding protein A6 (calcyclin) & 2.3 & 0.001 & 1 \\
XRCC6 & X-ray repair complementing defective repair 6 & 1.6 & 0.016 & 1 \\
\hline * & & & &
\end{tabular}

